\begin{tabular}{|c|c|c|c|c|c|c|}
\hline \multirow{4}{*}{ Impact Factor: } & ISRA (India) & $=3.117$ & SIS (USA) & $=0.912$ & ICV (Poland) & $=6.630$ \\
\hline & ISI (Dubai, UAE & $=0.829$ & РИНЦ (Russia & $=0.156$ & PIF (India) & $=1.940$ \\
\hline & GIF (Australia) & $=0.564$ & ESJI (KZ) & $=8.716$ & IBI (India) & $=4.260$ \\
\hline & JIF & $=1.500$ & SJIF (Morocco & $=\mathbf{5 . 6 6 7}$ & OAJI (USA) & $=0.350$ \\
\hline
\end{tabular}

\begin{tabular}{|c|c|}
\hline $\begin{array}{l}\text { SOI: } \frac{1.1 / \mathrm{TA}}{} \\
\text { International Sc } \\
\text { Theoretical \& A }\end{array}$ & $\begin{array}{l}S \text { DOI: } 10.15863 / T A S \\
\text { ientific Journal } \\
\text { pplied Science }\end{array}$ \\
\hline p-ISSN: 2308-4944 (print) & e-ISSN: 2409-0085 (online) \\
\hline Year: 2019 & Volume: 72 \\
\hline Published: 30.04 .2019 & http://T-Science.org \\
\hline
\end{tabular}

SECTION 14. Journalism (history, innovations, practices).
QR - Issue

QR - Article

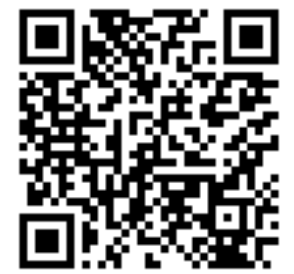

Gulnora Vohid qizi Zakirova

Researcher of National university of Uzbekistan,

Tashkent, Republic of Uzbekistan

\title{
FEATURES OF WOMEN'S PUBLICATION: TYPOLOGIES AND UPDATING THE THEME SCOPE
}

\begin{abstract}
The author reviewed the typology of modern women's online magazines in Uzbekistan and abroad. In addition, the author conducts their classification of modern women's online magazines on the basis of theoretical and typological analysis, identified types of publications and identified development trends.

Key words: online journal, women's journalism, female journal, typology, classification, media, online magazines.

Language: English

Citation: Zakirova, G. V. (2019). Features of women's publication: typologies and updating the theme scope. ISJ Theoretical \& Applied Science, 04 (72), 481-488.

Soi: http://s-o-i.org/1.1/TAS-04-72-61 Doi: crossef https://dx.doi.org/10.15863/TAS.2019.04.72.61

\section{Introduction}

The development of Internet technologies is qualitatively changing the structure of the media, making significant adjustments to the activities of the media sphere. In the process of popularization of Internet resources, a gender-oriented approach has emerged to consider the specifics of a network media structure [1]. The period of the organization of women's online magazines was designated in the second half of the 90s. XX century., At the beginning of the new century, the attention of publishers to this press has increased [2]. The reasons for the revitalization of the newest media segment being investigated were reduced to the popularization of online media, the growth of the audience, the organization of media projects that were not

organization of women's online magazines was designated in the second half of the 90s. XX century., At the beginning of the new century, the attention of publishers to this press has increased [2]. The reasons for the revitalization of the newest media segment being investigated were reduced to the popularization of online media, the growth of the audience, the organization of media projects that were not represented in the information environment, and the expansion of media companies. The typology of women's online journals is a field that has not been practically studied in the scientific community; meanwhile, the typological analysis of these publications and the definition of types contribute to the consideration of the specifics of the system of women's online periodicals.
\end{abstract} represented in the information environment, and the expansion of media companies. The typology of women's online journals is a field that has not been practically studied in the scientific community; meanwhile, the typological analysis of these publications and the definition of types contribute to the consideration of the specifics of the system of women's online periodicals. The development of Internet technologies is qualitatively changing the structure of the media, making significant adjustments to the activities of the media sphere. In the process of popularization of Internet resources, a gender-oriented approach has emerged to consider the specifics of a network media structure [1]. The period of the
Foreign overview: women's internet magazines in the Russia

At the present stage in the Internet space, the following means of mass communication, focused on the female segment: the women's Internet press, women's portals, websites of women's organizations, women's blogs, women's social networks. Women's periodicals presented on the Internet, it is advisable to consider it as women's magazines. First, they unite topics that correspond to the information interests of the female audience. Secondly, information is updated on these resources daily, or weekly, or as materials are 


\begin{tabular}{|c|c|c|c|c|c|c|}
\hline \multirow{4}{*}{ Impact Factor: } & ISRA (India) & $=3.117$ & SIS (USA) & $=0.912$ & ICV (Poland) & $=6.630$ \\
\hline & ISI (Dubai, UAE & $=0.829$ & РИНЦ (Russia) & $=0.156$ & PIF (India) & $=1.940$ \\
\hline & GIF (Australia) & $=0.564$ & ESJI (KZ) & $=8.716$ & IBI (India) & $=4.260$ \\
\hline & JIF & $=1.500$ & S.JIF (Morocco) & $=5.667$ & OAJI (USA) & $=0.350$ \\
\hline
\end{tabular}

prepared (but at least once a year). Thirdly, although the publications contain information of a news nature (news from the life of "stars", the fashion industry, the medical field), however, these thematic sections do not require frequent updates (unlike political, economic news blocks of Internet information newspapers). Fourth, informational genres used in publications (note, interview) are not predominant, informational and analytical (review, letter, article, commentary) and artistic and journalistic (essay, sketch) materials that allow most fully to reveal the subject-specific originality, to choose ways of describing and depicting reality (phenomena, events, heroes).

Women's online press is divided into online and electronic journals. Women's electronic journals (offline editions, modified online versions of traditional media) include online women's print journals, for example, "Liza" (http://www.lisa.ru), "Cosmopolitan" (http: // www. cosmo.ru), "Vogue" (http://www.vogue.ru), (http://www.glamour.ru), (http://www.samaya.ru), (http://www.wh-lady.ru), (http://www.9months.ru), (http://www.ellegirl.ru) and etc. The electronic version differs from the print edition in a number of typological features: structure, authoring, periodicity, etc. The modified online versions are organized I'm a publisher of women's magazines, the creation and promotion under the already known name guarantees the growth of readership, it promotes the formation of the image of the publication, promotion of the brand.

Women's online magazines (online editions) include publications that operate only on the Internet, which have no printed analogues, are engaged in the preparation and distribution of information addressed to a female audience.

In the process of organizing women's online journals, determining their intended purpose, which is directly related to the interests of the classroom group, is essential. According to a study conducted by the psychological department of Moscow State University, women on the Internet are interested in the following information: humor, culture, literature and art, education, leisure and hobbies, news. Women are more than men interested in information about education (54 and 41\%, respectively), culture and art (62 and 41\%), travel and tourism (35 and 22\%), family and children (22 and 10\%), medicine and diets (36 and $13 \%)$, leisure and hobbies (48 and 33\%). In contrast, there are fewer female users than men who are interested in information about programs and computing equipment (30 and $74 \%$, respectively), Internet updates (38 and 59\%), sports (13 and 20\%), products and prices (27 and $44 \%$ ), policies (20 and $35 \%$ ), as well as information "for adults" (18 and $41 \%$ ) [3]. Subsequent studies of the behavior of the female Internet audience [4] revealed its characteristic features: the need for communicative communication, creative implementation, and recreation. The most attention of this segment is used by the topics of the relationship between the sexes, cooking, women's health and fashion.

Information interests of the audience group are taken into account in the activities of women's Internet resources. Thematic fields ("fashion and beauty", "interpersonal relations", "health", "children", "home economics") are prevalent in women's network projects, their development in the direction of meeting the information expectations and needs of the women's group is one of the main conditions for successful operation.

In the course of the formation and development of the women's network press, there have been two directions in its organization: the first is the creation of a media product focused on the attention of a mass audience, obtaining a high rating, attracting advertisers; the second is the opening of a resource that ensures the implementation of a creative project that promotes communicative communication, the elimination of the information vacuum in the sphere of women's interests.

Based on the fact that the women's press refers to numerous spheres of female life (fashion, health, pedagogy, etc.), one can speak of women's differentiation network logs on types. Classification according to the classroom and subject-thematic characteristics allows to identify several types of women's online publications.

The study of women's online magazines engaged M. Kolesnikova, it analyzed the mass of women's online publications. As their distinguishing feature, the author identifies the thematic originality, which, according to the researcher, is limited to the following structures of a woman's life: “cooking, beauty secrets, cosmetics, family relationships, dating, growing houseplants, handicrafts, jewelry, shopping. In a word, everything that is interesting for women "[5]. It is noteworthy that the identified thematic aspects make it possible to classify the type of mass women's web magazine considered by $\mathrm{M}$. Kolesnikova as a mass universal. The Women's Network Universal Magazine is an Internet-based publication that publishes materials prepared specifically for this media, updated at regular intervals, covering the many areas of a woman's life that are related to her interests due to the functions of her wife, mother, and housewife.

Women's online universal journals are the predominant type of publications on the Internet (for example, myJane.ru, WomanJournal.ru, Devichnik, etc.). The organization of the publication, positioning itself as a women's universal, that is, covering a wide thematic spectrum, interesting to potential audiences, regardless of their professional status, political views, or confession, makes it possible to rely on mass demand. These journals represent the most popular 


\begin{tabular}{|c|c|c|c|c|c|c|}
\hline \multirow{4}{*}{ Impact Factor: } & ISRA (India) & $=3.117$ & SIS (USA) & $=0.912$ & ICV (Poland) & $=6.630$ \\
\hline & ISI (Dubai, UAE & $=0.829$ & РИНЦ (Russia) & $=0.156$ & PIF (India) & $=1.940$ \\
\hline & GIF (Australia) & $=0.564$ & ESJI (KZ) & $=8.716$ & IBI (India) & $=4.260$ \\
\hline & JIF & $=1.500$ & SJIF (Morocco & $=5.667$ & OAJI (USA) & $=0.350$ \\
\hline
\end{tabular}

projects in the category of women's resources, which is confirmed by rating statistics. Large media companies are interested in their promotion and popularization. The development of the media market is influenced by the law of the correspondence of supply and demand, "as the information needs of certain public groups increase, the demand for media products also increases. He calls the corresponding proposal" [6], which vividly confirms the development of network universal journals. [15]

In women's online universal magazines there is the same subject as on the pages of the popular print women's press, they are apolitical, distanced from economic issues, their attention is focused on fashion, home economics, women's health, children's pedagogy, gossip, interpersonal relationships. The problem-oriented orientation of the women's network universal periodicals is limited to the following targets: to help a woman look beautiful in accordance with fashionable standards, to be healthy, to normalize personal relationships, to help in raising children, to improve family life.

The specifics of online media introduces changes in the themes of publications and the process of its coverage. First, the definition of themes occurs with the participation of an audience group (in the forums, in the comments to the articles, in the publications of the readers). Secondly, the number of materials increases. Thirdly, the use of links and hyperlinks makes women's online magazines more traditional and more informative than traditional ones.

Women's online magazines of fashionable lifestyle (life style) - periodicals presented on the Internet, addressed to a female audience, informing about the development of the fashion industry, forming ideas about fashionable lifestyle (for example, FashionTame.ru, FashionWalk.ru and others). The concept of the publication includes thematic areas limited to the scope of fashion (clothing, cosmetology, perfumery, design, leisure, information about famous people). The structure of the journals in question does not include sections related to housekeeping, child-rearing, and in defining the characteristics of the classroom group, the key parameters are such criteria as material status, age. The readership of these publications is girls, young women with an average and high level of wealth, whose position allows not only to read publications about new trends in the field of fashion, but also to buy fashion products, information about which is posted in the magazines in question. Women's online publications of fashionable lifestyle repeat the thematic concept of women's elite magazines (Cosmopolitan, Glamor, etc.).

The concepts of "Internet gloss", "lifestyleInternet media" have been established in the Internet environment. The first definition characterizes the segment of Internet publications that popularize fashionable standards and attributes, the semantic content of the second is interpreted as the designation of a group of media represented on the Internet, focused on the formation of ideas about a comfortable, beautiful life. Women's network universal magazines aimed at attracting a mass audience can be considered as "Internet gloss", they include the "lifestyle" direction, but in addition to it they integrate into their typological model a number of other thematic areas.

Women's online medical journals - periodicals, presented on the Internet, addressed to the mass female audience, popularizing information about women's health. It should be noted that attention in the press to the topic of women's health was updated: a series of printed women's health journals are published, they have electronic versions, and, in addition, women's online health magazines are published (for example, "Womenhealthnet", "Mother and Child", etc.).

Women's online religious magazines periodicals, operating on the Internet, are addressed to women believers. The network has been created women's Orthodox magazines ("Matrony.ru" (20062011), "Mironositsy.ru") and the Muslim edition ("darling"). [3]

Women's online magazines sewing, handicrafts periodicals, presented on the Internet, addressed to the female audience, posting information about fashionable clothing styles, its production, acquainting with the technology of needlework craftsmanship. Among the designated editions, the following magazines stand out: on fashionable clothes, sewing, embroidery, etc. (for example, Osinka.ru magazine, Atelier.com, etc.).

Women's Network Literary Journal is a periodical published on the Internet that hosts literary publications focused on a female audience. For example, the publication "Outline". The presence of advertising in the magazine is minimal, thus, the implementation of a creative project in the concept of publication is predominant.

Non-commercial projects include the Katoga women's online magazine, its main goal is the organization of virtual communication, "help and support" [7]. The network publication "Katoga" is an individual author's project, created not on a commercial platform, it is positioned as a publication of one author.

The diversity of women's Internet resources is motivated by the growing interest of the audience to the network space, in which the communicative, cognitive, professional, and recreational activities of the individual are realized. The publishers of women's online magazines are mainly media companies interested in expanding media assets through women's resources. So, the owner of myJane.ru is the MediaFort group, which includes women's social networks; "WomanJournal.ru" is owned by Milanor LLC, which unites the women's Internet magazine Passion.ru, the portal leLuxe.ru, 19 women's websites 


\begin{tabular}{|c|c|c|c|c|c|c|}
\hline \multirow{4}{*}{ Impact Factor: } & ISRA (India) & $=3.117$ & SIS (USA) & $=0.912$ & ICV (Poland) & $=6.630$ \\
\hline & ISI (Dubai, UAE & $=0.829$ & РИНЦ (Russia) & $=0.156$ & PIF (India) & $=1.940$ \\
\hline & GIF (Australia) & $=0.564$ & ESJI (KZ) & $=8.716$ & IBI (India) & $=4.260$ \\
\hline & JIF & $=1.500$ & SJIF (Morocco & $=5.667$ & OAJI (USA) & $=0.350$ \\
\hline
\end{tabular}

that form the media project ("media space") "Women's passions". The increase in attendance of the studied resources indicates their demand, for example, "myJane.ru", according to 2009, occupied the 29th position in the rating of women's sites "Rambler Top 100" (April), the monthly number of visitors was more than 119 thousand people (March April), in 2011, the monthly attendance exceeded 2 million people (May).

The model of a mass women's online magazine is designed for a reader segment with the following characteristics: age range - up to 40 years old, level of financial security - average and above average. The classroom group takes an active part in the work of network journals, which leads to a change in the nature of the role of the reader, from a passive consumer of information, he turns into an author.

So, at present, there is a development of women's online magazines, which is caused by the expansion of online media activities and their functional specificity. The tendency of organizing commercial projects of network journals and publications aimed at the implementation of creative ideas, the coverage of topics that are not popular in the mass periodicals was marked. The first group is characterized by the construction of a typological model focused on obtaining economic profit. At the base of its typeforming features are approved the criteria, which, in general, determine the parameters of the publication, allowing to rely on the effective project activity: large media companies act as a publisher, groups of wealthy women are chosen as the auditorium segment. Nonprofit women's network projects are presented, in particular, religious magazines, as well as a literary publication. In the role of their publishers are individuals, as the main goals of their organization are the following: coverage of the thematic aspect, which is not considered in the mass press, the realization of creative possibilities, the initiation of communication between the audience. The democratic nature of the network environment makes it possible to publish publications in which the minimum number of employees is involved, as a result of which it becomes possible to organize a copyright journal produced by one person, combining the duties of an editor, author, web designer.

Women's journalism on the Internet is one of the fastest growing segments. It is noteworthy that so far there is not only a special study of this issue, but also a study of Internet journals in general. The article attempts to fill this gap by referring to the analysis of the Internet media of Runet, which position themselves as women's magazines.

Keywords: women's journalism, Internet magazines, analysis of Internet media Runet. [13]

In the light of the problem of the establishment and development of women's magazines in the domestic information market, let us turn to the analysis of the Internet media of Runet, which position themselves as women's magazines. In this case, we will take into account the following signs that are essential for attributing a resource to the media: "the professional nature of information production and specialization in this type of activity; the presence in the name or logo of the site generic features that indicate belonging to the media (for example, "newspaper", "magazine", "television", "channel", "agency", etc.); positioning itself as a producer of information; the content of the site indicates that the creators identify it with activities that coincide with the activities of the media ("edition", "source", "interview", "transfer", etc.): reflected in the content of the life of the society, and not only the activities of the subject of information production; a combination of different types / types of materials or programs belonging to different genres; frequency of content update at least once a month; availability of an address where users can find the site creators, contact them "(1). It should be remembered that, speaking of online media or the electronic version of traditional media, we cannot unambiguously determine whether it is a newspaper, magazine, TV, radio or something else related to the multi-format of the network media.

There are many different classifications of Internet publications, however, theorists and media practitioners see an obvious and non-objectionable approach in which online media are considered relative to their offline parents. Such an approach is reasonably presented in the works of M. M. Lukina, which identifies "clones", "hybrids" and the network media proper (2). From this point of view, women's online magazines can be classified as follows.

1. Equivalent copies of traditional media ("clones"),

Most of the "clones" in the Internet catalogs, since their creation does not require significant efforts: a copy of the printed publication is placed on the global network. Most often this occurs somewhat later than the date of the printed number, in some cases, earlier or at the same time. This type of Internet presence in the segment

Those women's magazines usually have low-cost domestic, most often regional publications.

2. Modified online versions of traditional media ("hybrids"). [4]

The electronic version of the publication is not a copy of the printed issue, but lives an independent life, first of all it is connected with the daily update. At the same time, materials are adapted for their perception on a computer screen, taking into account the possibilities of Internet technologies associated with an increase in the amount of information (all materials on the topic available in the editorial office can be published), updating information online, publishing hyperlinks that expand the information field (3) .

All modern women's glossy magazines have their offices on the Internet, referring specifically to the "hybrid" type. In addition to the materials 


\begin{tabular}{|c|c|c|c|c|c|c|}
\hline \multirow{4}{*}{ Impact Factor: } & ISRA (India) & $=3.117$ & SIS (USA) & $=0.912$ & ICV (Poland) & $=6.630$ \\
\hline & ISI (Dubai, UAE & $=0.829$ & РИНЦ (Russia) & $=0.156$ & PIF (India) & $=1.940$ \\
\hline & GIF (Australia) & $=0.564$ & ESJI (KZ) & $=8.716$ & IBI (India) & $=4.260$ \\
\hline & JIF & $=1.500$ & SJIF (Morocco & $=5.667$ & OAJI (USA) & $=0.350$ \\
\hline
\end{tabular}

published in the print edition, there is an archive of publications, additional articles on the most relevant topics, which (like the site as a whole) have visitor counters (ratings), readers vote and discuss materials in the forums.

Forums - peculiar analogues of the round table one of the most important headings of online media. Here everyone can ask a question of interest and get an answer from the same users as him, discuss the readings with them. It is noteworthy that more and more forum materials help thematic content of magazines, offering new topics, problems, situations. This also contributes to the numerous questionnaires posted in the online versions of women's magazines. Publications stimulate readers with contests, prizes, and the publication of the best ideas on the pages of the printed version. [5]

3. Actually network SAS not having offline prototypes.

The network has generated its own, specific media. One of these tools is the online magazine (the English name is "e-zines >>", abbreviated from "electronic magazines" - "electronic journals"). Currently, there are a large number of publications on the Internet that present themselves as women's magazines. They are focused mainly on a socially active, business-like, technically advanced, fairly well-to-do female audience. Here are the most characteristic of them. [6]

"Cultural life of the South of Russia"

The journal "Women's Passions" is published from June 26, 1999 on Mondays and has an infotainment character. The magazine's audience is modern women, independent and independent. Thematic content - cooking, beauty secrets, cosmetics, family relationships, dating, indoor gardening, handicrafts, jewelry, shopping, etc. In accordance with this, eleven rubrics are formed, uniting into a single whole the key concept of "passion": "Passionate cook "- a heading for home cooks, present and future; "Passionate and beautiful" - tips on caring for yourself; "Family Passions" - tips on how to find your soul mate and get married, how to save a family, etc .; "Fruits of Passion" - a section on children and their upbringing; "Intimate Passions" articles on intimate topics; "Passionate Dating" - the opportunity to meet, start a correspondence, flirt; "Passion to spend money" - information about bargains; "Handicraft is my passion"; "Passionate florist"; "Passionate horoscope"; "Jewelry passion." Materials of the new issue are presented on the main page, with each rubric containing an archive of publications by topic. A significant amount of materials are translated articles. The magazine supports the readers' forum to discuss the problems proposed by the attendees. [8]

"Devichnik" magazine began to be published on April 15, 1998. The publisher and editor, O. Dunaeva, performs coordinating and organizing functions, and editorial staff work independently in different cities and countries, searching for authors, selecting and arranging materials (this is one of the most common forms of organizing an Internet publication). In the very first issues of the magazine there were only four small rubrics, but gradually "Hen Party" turned into a large project and gathered a team of regular authors around itself. The main headings: "Theme", "Life", "Interview", "Style", "Hostess", "Needlework", "Kid", "Muse", "Hihanki", "Cinema", "Tourism". In general, "Hen Party" can be attributed to the same type as "Women's Passion" - a mass edition. [11]

"Woman Journal" [www.WMJ.ru] contains a traditional set of bookmarks, headings: fashion, stars, beauty and health, love and sex, psychology, home and food, family and children, leisure and hobbies, magic. At the same time on the main page there are portraits of expert consultants - professional doctors, psychologists, makeup artists. Secular news is placed in the "Starfall" section and accompanied by photos. Various games, contests are offered. [12]

The electronic magazine about beauty, health and fashion "Beauty online" [www.krasota.ru] consists of two large sections ("Everything for you" and "Professionals") and a number of general headings. The purpose of the publication - the coverage of issues related to human health and beauty. The materials of the journal are of interest both for ordinary users and specialists, published articles are stored in the archive. The authors and consultants are experienced and well-known specialists - hairdressers, cosmetologists, fashion designers, nutritionists, plastic surgeons, etc. Updating the magazine - one or two new articles a day, plus a newsletter. The publication offers a search for resources by topic (salons, online stores, training, etc.); contest of masters, review of events. The forum is supported, consultations are given. In addition, there is a kind of labor exchange that helps women in their search for work. [10]

The magazine "Jane" [www.myjane.ru] offers readers to break away from the everyday hustle and bustle, to enjoy reading the proposed information, which will help to keep abreast of all the most interesting and important events. The rubrics are traditional for most women's publications (everything about fashion, beauty, style, health; library of articles, news, horoscopes, forums; online psychological counseling service), while editor-in-chief Yevgenia Kulikova addresses readers with the proposal to become co-authors of the magazine, writing about the news, send feedback, suggestions and suggestions. [14]

There are a huge number of women's magazines in the Internet space, and they are developing practically in the same way as printed ones. It is dominated by publications of a universal nature, designed to meet the information needs of women in various areas of their lives. Specialized publications, 


\begin{tabular}{|c|c|c|c|c|c|c|}
\hline \multirow{4}{*}{ Impact Factor: } & ISRA (India) & $=3.117$ & SIS (USA) & $=0.912$ & ICV (Poland) & $=6.630$ \\
\hline & ISI (Dubai, UAE & $=0.829$ & РИНЦ (Russia) & $=0.156$ & PIF (India) & $=1.940$ \\
\hline & GIF (Australia) & $=0.564$ & ESJI (KZ) & $=8.716$ & IBI (India) & $=4.260$ \\
\hline & JIF & $=1.500$ & SJIF (Morocco & $=5.667$ & OAJI (USA) & $=0.350$ \\
\hline
\end{tabular}

primarily devoted to the beauty industry, are actively developing. The group of socio-political publications is almost undeveloped.

The share of the female audience of the Internet is constantly growing, there are more and more new online publications designed for it. Determining the place of women's magazines in the online media system is important not only from the point of view of theoretical understanding of the new phenomenon, but also from the point of view of creating successful products in the field of online media. [16]

\section{Women's publication in Uzbekistan: typologies, updating the theme scope}

Women's publications in Uzbekistan have almost a century of history. These publications have contributed significantly to the social activeness of women in Uzbekistan, which has traditionally been regarded as a "subgroup of society", and has contributed to the resolution of "women's issues" in society. As the Russian researcher EASola Sokolova pointed out, "the role of women in the world and the gender issues that they have in their quest for equal access to men have been strongly entrenched in the humanitarian sphere and social consciousness. Therefore, academic research on the ways and conditions of media influence on the formation of gender perception has become an actual "scientific issue.

During the years of independence, "the increase in the number of women's publications in the national press can be attributed to the increased demand for such newspapers and magazines in the information market and the increase in women's social activity in society. The number of women's publications is around 30 in the country. They were created mainly in 2006-2010 ". In the national press, the politically motivated approach of women also coincides with those years. The majority of them are established by the Women's Committee of the Republic and its regional offices.

Saodat magazine, which operates in our country in the 20th century and has a direct impact on raising the socio-political activity of women in the country today, is the first of its kind in this area.

Saodat magazine is distributed nationwide by the Women's Committee of Uzbekistan. The magazine has been published since 1925 (the first issue was called "The New Way"). In 1936, it was called "Bright Wedding", and in 1938 it was called "Bright Life". Nowadays, this edition is published in 34 pages, about 8,000 copies.

The new pillars of the magazine have a special place in the "Women and Politics" pillar. The "Women and Politics" magazine publishes essays and essays on the activities of women in politics, their family life. For example, in the issue number 7 of the magazine in 2018 an article by Muhtabar Khusanova, candidate of the Legislative Chamber of the Oliy Majlis of the Republic of Uzbekistan, "Our Family Law Center" can be found. This article focuses on the ongoing reforms in Uzbekistan to pursue a wave of dictatorships in the life of our Uzbek women, to look at it in a new way and to raise our children as mature people.

The author admits that today's policies of leading women abroad are correct and, if necessary, we have to work together to achieve our goals, that is, execution of draft resolutions, decrees and orders. Such an opinion creates a sense of self-confidence in the socio-political sphere of women in all aspects of political leadership in our country. In addition, other conversations, portraits and essays published in this column give interesting materials about prominent women of modern age, women-MPs working in various representative bodies, well-respected women who work in different fields of national economy.

Other pagans also have readable material. For example, an article titled "The Ration of Mother's Milk," published in the 5th issue of the magazine, gives an interesting piece of information. In particular, it is thought about the impact of breast milk on the health of the baby and its future health. Today, this approach to the health of the people during the growing ecological threats today is certainly attracted by the attention of the female audience. In this issue another article titled "No will be" is about the life of Mukhabbat Yuldasheva, resident of the Kurgantepa village of Andijan region, where her entering the business sector has been struggling to implement her ideas, attracting credit funds to her family members today, most of his story is about his pure labor and his example. Nowadays, such women are, in fact, the "Future of Uzbekistan", the future of Uzbekistan, is making its fascinating contribution to the future of our youth. Of course, this kind of material about women will have a positive effect on the audience. [9]

The headings on each issue of the journal vary widely depending on the different themes and styles. For each published material, it is considered to be a meaningful pillar.

Saodat is widely promoting the single state policy on women. Along with this, the activity of nongovernmental publications in the information market is increasing. For example, women's publishing houses such as "Sogdiana", "Saodat", "Tadbirkor ayol", "Mo'minalar" can be mentioned. In particular, it is not a mistake to say that Sogdiana women's weekly meeting housewives can fully meet their information needs. Various articles, interviews and consultations on housewives' health, children's upbringing, family relationships, psychologist counseling, cookery, and secrets are regularly published.

However, it should be noted that, although subjects may be attractive to the subject, but the materials are of a pleasant nature, this publication is 


\begin{tabular}{|c|c|c|c|c|c|c|}
\hline \multirow{4}{*}{ Impact Factor: } & ISRA (India) & $=3.117$ & SIS (USA) & $=0.912$ & ICV (Poland) & $=6.630$ \\
\hline & ISI (Dubai, UAE & $=0.829$ & РИНЦ (Russia) & $=0.156$ & PIF (India) & $=1.940$ \\
\hline & GIF (Australia) & $=0.564$ & ESJI (KZ) & $=8.716$ & IBI (India) & $=4.260$ \\
\hline & JIF & $=1.500$ & SJIF (Morocco & $=5.667$ & OAJI (USA) & $=0.350$ \\
\hline
\end{tabular}

far from its typological approach to qualitatively analyzing "serious" issues. This dramatically limits the ability of the publication to have potential audiences.

The newspaper "Gulchehralar" publishes about 13 thousand copies in "Saodat" magazine in April 1991 , once a month. The main issue of the newspaper is the samples of creative women's works. The essays, essays, and articles that tell us about the realities of our Ibratam are published. In the "Read" column samples of Uzbek and world literature are given. The final page is a minstrel of fans, and there is a post on the "Letters to Ophthalmus" in the editorial office. It contains a comprehensive and analytical response to the messages from customers. It may be said that typologically this publication has become a popular literary art publication of women.

In the Internet, there are resources that cover the lives and activities of women in the Republic, which are mainly the traditional versions of paper women's newspapers and magazines. They also seek to publish the latest news and articles quickly in their social networking sites, such as facebook, and thus respond to the information needs of girls and women who can effectively use ICT. An example is facebook.com/sugdiyona.uz. This site, along with materials about women's socio-political life, can answer all of their questions. [8]

However, today's clients apply more often to the joint web-site of the two leading magazines republican.uz. This online publication has been operating since 2014. It provides the best materials published in leading chapters of both paper publications. The site's upgrade is on a regular basis. Of course, happiness-gaming.uz is not inferior to anything. It does not contain full-fledged multimedia genres, infographics, and other features of internet journalism. However, this resource has its own regular audience among the audience. By examining the number of years 2018, we can say that they are much better. [7]

It is certainly not possible to purchase any published magazine. But we can see all the magazines electronically through this web site. They can read the magazine to carry out psychological support and full explanatory work so that our women can find their place and change their outlook, even when they see the attitude of women around them. On the website www.host-goggum.uz you can find electronic magazine "Bekalar", "Jahonga mashhur ayollar", "Journey to the heart", "Unsigned articles", "Nasr", "Khanlarimiz sporti", " , "Chevarxana". Nearly 193200 customers per day will enter the data and review the information they need.

The newspaper "In the family circle" was founded by nine founders. Among them are the Women's Committee. The Week has been published since 2012. The main materials of the weekly workshops are given in such topics as "Topic",
"Today's Speech", "Source of income", "About aunt", "Mustacheam family", "Man yourself", "Healthy life", "Invisible childhood", "Family doctor" go. Typically, this publication is considered as a family, with a third of the materials in it devotedly to women. Therefore, this pomegranate can also be included in the editions.

It is also possible to mention publications for women published in the regional Women's Committees.

Iqbol newspaper is a socio-political, culturaleducational publication of Andijan women's women, starting November 1, 1997. The eight-page event will feature 3,000 copies. The newspaper covers a wide range of topics, broadens criticisms, and publishes articles on the topic of "Today's Speech", "The Tongue of Tongue", "Hidoyat nuri" and "Our Values".

Another aspect of the newspaper is that it does not raise local press, but it is up-to-date, "untouched," raises issues that are causing debate. In the article titled "The problem of corruption of the century" in the issue of September 20, 2018, the article focuses on the current issues of the current situation, the measures to prevent the bribery of our times, and the interview with representatives of the relevant sector in Uzbekistan.

On November 8, 2018, an international conference titled "Women's Role in Democratic Modernization and Modernization of the Country: Uzbekistan's Experience and International Practice" was held in Uzbekistan with support from the United Nations and other international organizations. As noted by the media, the issues of expanding the role and capacity of women in public administration and the importance of gender equality, women's employment and entrepreneurship, their social protection and their health care were discussed in detail.

It has been said that today women should be educated in a conscientious manner by bringing them to the politics of the world, and not only in Uzbekistan, but also in Afghanistan, Tajikistan, and Kazakhstan.

During the study of the activities of women's publications in the Republic, several laws were identified. Firstly, not all publications are specialized in women's issues. Secondly, the number of analytical, critically and controversial articles on the daily life and activities of women in both private and publicowned publications is less than 2017 .

Over the past two years, the number of critical and analytical materials has increased, but not in terms of quality. Third, the majority of the materials are of formal nature, with almost no emphasis on the human personality of women. Fourthly, it is desirable to extend the scope of genres and topics in most publications, and to increase the content of the women's inner world.

It does not mean that these publications are fully covering gender relations. The main reasons for this 


\begin{tabular}{|c|c|c|c|c|c|c|}
\hline \multirow{4}{*}{ Impact Factor: } & ISRA (India) & $=3.117$ & SIS (USA) & $=0.912$ & ICV (Poland) & $=6.630$ \\
\hline & ISI (Dubai, UAE & $=0.829$ & РИНЦ (Russia & $=\mathbf{0 . 1 5 6}$ & PIF (India) & $=1.940$ \\
\hline & GIF (Australia) & $=0.564$ & ESJI (KZ) & $=8.716$ & IBI (India) & $=4.260$ \\
\hline & JIF & $=1.500$ & SJIF (Morocco & $=5.667$ & OAJI (USA) & $=0.350$ \\
\hline
\end{tabular}

are the lack of awareness of journalists about gender issues and the fact that they do not understand the gender issue in the context of women's issues and that men and women are equally responsible for the development of society and the welfare of the family. Therefore, the following issues are addressed to our national press on the main issues of gender mainstreaming:

- Widespread coverage and promotion of consistent processes for the improvement of women's rights legislation;

- Consistent and systematic coverage of women's political participation processes in Uzbekistan;

- Promote the broader dissemination of women in leadership skills;

- broad coverage of women entrepreneurship activities, including women entrepreneurship based on innovative technologies;

- Publish more materials from lawyer and psychologist on domestic violence; provide journalistic inquiries;

- providing live lectures to mass audience, providing handouts, such as question-answer, expert advice, to meet women's everyday needs;
- broad coverage of activities of women in nongovernmental non-profit organizations.

\section{Conclusions}

In summary, Uzbekistan is focusing on women's activism in the development of society. During the years of independence, a number of special programs and projects at the level of state policy have been implemented in this direction.

During the years of independence, a number of special programs and projects at the level of state policy have been implemented in this direction. Media and other media are gaining momentum to support women's participation in social, economic, political, and cultural life. Significance of public-private and specialized women's publications is increasing in coverage of the role of women in public life and their activities in various spheres.

Our national press coverage of the women's role today should consistently and consistently reflect on the rights of women, the processes of their entry into politics, and the activities of women entrepreneurship, including those engaged in entrepreneurship on the basis of innovative technologies.

\section{References:}

1. Grishina, G. (2000). Woman in the Internet Web East-West: Women's Innovation Projects. Special edition. Retrieved 2019, from http://www.owl.ru/

2. Smeyuha, V. V. (2011). Transformation of the functional features of women's magazines in a historical context. Bulletin of Adygea State University. Ser. Philology and art history, Vol. 1, pp. 53-58.

3. Aretov, O. N. (2000). Gender Differences on the Internet: The Seventh Conference of Representatives of Regional Scientific and Educational Networks Relarn-2000. Informational and communicative technologies in education. Retrieved 2019, from http://www.ict.edu.ru

4. (2009, September 18). Women's preferences in Runet sites: young girls prefer Vkontakte.ru, older ladies - Odnoklassniki.ru. Rumetrika. Figures on the Internet. Retrieved 2019, from http://www.rumetrika.rambler.ru/review/2/4059

5. Gurevich, S. M. (1999). Economics of the media. (p.10). Moscow.
6. (2018). Journal Saodat, 5-6-7 in 2018.

7. (2018). The word "people" is 2018.

8. (n.d.). Retrieved 2019, from www.wcu.uz

9. (n.d.). Retrieved 2019, from www.saodat-gul.uz

10. Sokolova, E. A. (n.d.). Gendernye stereotipy v sovremennykh SMI kak informatsiey kommunikatsii. Journalism and Mass Communication. pp.71-72.

11. Mamatova, Y., \& Sulaymonova, S. (n.d.). Gold medals.

12. (n.d.). New issues of the newspaper "Sogdiana".

13. Sukhov, P. V. (2005). Runet's Internet Media: System Characteristics: Dis. ... Cand. philologist, science. Moscow. p. 85.

14. (2005). The media of Russia. Moscow. p. 350353.

15. Kolomiytseva, E. Y. (2008). Women's journals on the internet. The Cultural Life of the South of Russia. No. 2 (27).

16. Smeyuha, V. V. (2011). Journalism. Women's online journals: a theoretical and typological characteristic. p.50. 